\title{
Elevation dependency of mountain snow depth
}

\author{
T. Grünewald ${ }^{1,2}$, Y. Bühler ${ }^{1}$, and M. Lehning ${ }^{1,2}$ \\ ${ }^{1}$ WSL Institute for Snow and Avalanche Research SLF, 7260 Davos, \\ Switzerland \\ ${ }^{2}$ Cryos, School of Architecture, Civil and Environmental Engineering, École \\ Polytechnique Fédérale de Lausanne, 1015 Lausanne, Switzerland
}

Correspondence to: T. Grünewald (gruenewald@slf.ch)

Received: 20 June 2014 - Published in The Cryosphere Discuss.: 11 July 2014

Revised: 4 November 2014 - Accepted: 7 November 2014 - Published: 20 December 2014

\begin{abstract}
Elevation strongly affects quantity and distribution patterns of precipitation and snow. Positive elevation gradients were identified by many studies, usually based on data from sparse precipitation stations or snow depth measurements. We present a systematic evaluation of the elevationsnow depth relationship. We analyse areal snow depth data obtained by remote sensing for seven mountain sites near to the time of the maximum seasonal snow accumulation. Snow depths were averaged to $100 \mathrm{~m}$ elevation bands and then related to their respective elevation level. The assessment was performed at three scales: (i) the complete data sets $(10 \mathrm{~km}$ scale), (ii) sub-catchments (km scale) and (iii) slope transects (100 m scale). We show that most elevation-snow depth curves at all scales are characterised through a single shape. Mean snow depths increase with elevation up to a certain level where they have a distinct peak followed by a decrease at the highest elevations. We explain this typical shape with a generally positive elevation gradient of snow fall that is modified by the interaction of snow cover and topography. These processes are preferential deposition of precipitation and redistribution of snow by wind, sloughing and avalanching. Furthermore, we show that the elevation level of the peak of mean snow depth correlates with the dominant elevation level of rocks (if present).
\end{abstract}

\section{Introduction}

Complex orography is the main driving factor for the spatial heterogeneity of precipitation. When moist air masses are blocked by mountains, they are forced to ascend the mountain slopes. Declining air temperatures result in a cooling and a decrease of the saturation pressure of the lifted air parcels. Once the saturation level is reached moisture condensation leads to cloud formation and finally to the onset of precipitation. These processes are enhanced by further lifting which finally results in an increase of precipitation with elevation up to a certain maximum, which is reached when moisture becomes too depleted from the air mass. However, the interaction of clouds and precipitation particles with the local wind can strongly modify the precipitation patterns at the ground (Mott et al., 2014; Roe, 2005; Roe and Baker, 2006).

Orographic precipitation effects have been studied at a large range of scales for mountain regions all around the world. Most studies identified a distinctive increase of precipitation with altitude (e.g. Spreen, 1947; Peck and Brown, 1962; Frei and Schär, 1998; Blumer, 1994; Johnson and Hanson, 1995; Roe and Baker, 2006; Liu et al., 2011; Asaoka and Kominami, 2012). Contrary, Blumer (1994), Basist et al. (1994) and Arakawa and Kitoh (2011) reported on negative elevation gradients of precipitation.

For snow on the ground, positive correlation of precipitation and elevation are usually reflected in a general increase of snow depth or snow water equivalent (SWE) as reported by many studies (e.g. Rohrer et al., 1994; Bavera and De Michele, 2009; Lopez-Moreno and Stähli, 2008; Durand et al., 2009; Lehning et al., 2011; Grünewald and Lehning, 2011; Grünewald et al., 2013). However, other studies did not identify positive elevation gradients for their study sites and some even found negative dependencies of elevation and snow amount. For a study site in New Zealand, Kerr et al. (2013) could not identify elevation gradients of SWE, and no clear correlations between elevation and SWE were found 
for some inner-alpine regions in Switzerland (Rohrer et al., 1994).

Consequently, the shape of the elevation-precipitation relation can vary strongly even over small distances (e.g. Lauscher, 1976; Rohrer et al., 1994; Basist et al., 1994; Sevruk, 1997; Wastl and Zängl, 2008). This strong variability is attributed to the highly complex interaction of the weather patterns with the local topography. Sevruk (1997) assumes that "in a series of inner-alpine valleys following each other and having different orientation, slopes and altitude, the redistribution of precipitation by wind can be the dominant factor of its spatial distribution suppressing any other effects including the altitude". Other studies postulate an advective leeward shift of the local precipitation maximum, favoured by specific topographical and meteorological conditions (Carruthers and Choularton, 1983; Robichaud and Austin, 1988; Zängl, 2008; Zängl et al., 2008; Mott et al., 2014). Due to its lower fall speed, this shift is more pronounced for snow fall than for rain (Colle, 2004; Zängl, 2008). On a smaller scale, Mott et al. (2014) showed that orographically modified patterns of mean horizontal and vertical wind velocities affect particle trajectories of snow in the air. Reduced snow deposition rates on windward slopes and enhanced deposition on leeward slopes are induced by this process. Small-scale snowfall patterns over single inneralpine mountain peaks can, thus, differ significantly from those observed on a larger scale for large mountain ranges, where cloud formation processes tend to result in drier leeward slopes (Houze, 2012; Mott et al., 2014).

The thickness of the snow cover at the end of the winter season can serve as a proxy for the seasonally accumulated precipitation on the ground. However, Scipion et al. (2013) identified large differences between precipitation patterns obtained by a high resolution Doppler X-band radar and the final seasonal snow accumulation. These differences are attributed to several processes that affect the snow once on the ground; due to gravitational forces, snowflakes might immediately glide downslope if they land on sufficiently steep surfaces. Furthermore, the wind can redistribute the snow from exposed to sheltered locations (Gauer, 2001; Mott et al., 2010). The erosion by the wind is largest at higher altitudes, as wind speeds and exposure tend to increase with elevation. Moreover, driven by gravitation, snow is potentially moved downward by creeping, sloughing and avalanching (Bernhardt and Schulz, 2010; Gruber, 2007). Finally, snow melt, sublimation and phase transitions from snow to rain, especially in spring, might affect the cumulative amount of snow, particularly at lower elevations (Elder et al., 1991). In combination, these processes modify the elevation-driven precipitation signal stored in the snow cover. In summary, reduced snow amounts at crest level, in steep slopes and the lowest elevations are contrasted by enhanced accumulation in flat and protected areas at the foot of the slope. However, all these processes are characterised by a large spatial heterogeneity caused by the interaction with the local topography
(Blöschl, 1999). This variability is especially large at small scales (Shook and Gray, 1996; Watson et al., 2006) and results in a high spatial variability of the snow cover.

As most of the studies mentioned before are based on a limited number of gauges or weather stations, the potential bias of the results appears relatively large (Havlik, 1969; Sevruk, 1997; Grünewald and Lehning, 2014). Inadequate spatial station coverage, especially in high altitudes (Blanchet et al., 2009; Daly et al., 2008; Sevruk, 1997; Wastl and Zängl, 2008) and the large potential measurement error of precipitation, especially in exposed areas (Rasmussen et al., 2001, 2011; Sevruk, 1997; Yang et al., 1998), are important factors that might impact on the results of these studies. Owing to the rapid development of remote sensing techniques such as laser scanning (LiDAR), high spatial resolution data sets have recently become available for the snow cover (e.g. Deems et al., 2013; Grünewald et al., 2010, 2013; Kirchner et al., 2014). Furthermore, significant advances in the development and application of Doppler radars for precipitation quantification have been reported (Scipion et al., 2013; Mott et al., 2014). However, the resolution of these systems is still insufficient to reflect the small scale variability of precipitation and snow fall close to the surface.

To our knowledge there are only two studies on elevation gradients of snow that are based on such area-wide data: Grünewald and Lehning (2011) compared elevation gradients calculated from airborne LiDAR surveys with simple climatological and snow-station-based gradients for two small study sites in the eastern Swiss Alps. Principally Grünewald and Lehning (2011) identified a positive correlation of SWE and elevation, but they also recognised strong deviations between the 2 sites, 2 consecutive years and between the 3 different approaches. For the LiDAR gradients they found that the relation between elevation and snow depth levelled at a certain altitude and finally even decreased. Simultaneously with our study and also based on a LiDAR data set, Kirchner et al. (2014) analysed elevation gradients of snow depth of a $53 \mathrm{~km}^{2}$ mountain catchment in the southern Sierra Nevada of California. They found a strongly positive elevation gradient that transits to a sharp decrease in the highest elevations. They suggest that "a reduction in precipitation from upslope lifting, and/or the exhaustion of precipitable water from ascending air masses" (Kirchner et al., 2014) might be the reason for the shape of the snow depthelevation relationship. Based on multi temporal point measurements, similar shapes had already been identified by Turcan (1975) and Holko (2000) for a $35 \mathrm{~km}^{2}$ basin in the Low Tatra mountains (Slovakia). Both studies report on positive elevation gradients of snow below the tree line and a distinct decrease of snow storage in the summit region. They explain this pattern by wind exposure redistributing the snow from the higher elevations to the upper forest boundary area.

From these findings the question arose, if such a shape is generally characteristic for the snow depth-elevation relationship. The availability of a large data set consisting of 
area-wide high resolution snow depth data from different mountain regions (Grünewald et al., 2013) now allows us to test this hypothesis. Based on Grünewald and Lehning (2011), we systematically analyse snow depth elevation gradients for different scales ranging from slope transects to the entire catchments or mountain sites. In addition to the identification of typical shapes we also aim to explain the altitude of the snow depth maximum. The novelty of this study lies in the fact that for the first time high resolution data from different mountain regions are analysed.

\section{Data}

\subsection{Airborne laser scanning (ALS)}

Recent years have seen an increasing number of applications of airborne laser altimetry (ALS or LiDAR) for snow studies (e.g. Deems et al., 2006, 2008; Grünewald et al., 2013; Grünewald and Lehning, 2011; Lehning et al., 2011; Trujillo et al., 2007, 2009). High resolution snow depth maps are calculated by subtracting two digital surface models (DSM), one obtained in snow-covered and one in snow-free conditions. It has been shown that ALS is a valid method for gathering area-wide snow depth data (e.g. Hopkinson et al., 2004; Deems and Painter, 2006; Deems et al., 2013), and that vertical accuracies are in the range of centimetres to a few decimetres (Grünewald et al., 2010; Bollmann et al., 2011; Hopkinson et al., 2012; Deems et al., 2013). In principal, data sets obtained by helicopter-based LiDAR appear to be more accurate than data sets gathered from aeroplanes (Grünewald et al., 2013). This is attributed to reduced flying height, terrain-following flight line of the helicopter and a better footprint in steep terrain due to the tilting sensor. Table 1 lists the measurement platform of the data sets analysed in this study. DSMs were calculated from the raw point clouds by averaging to regular grids with a cell size of $1 \mathrm{~m}$. The average point densities of the LiDAR raw point clouds depend on the measurement platform and were in the range of one (aeroplane-based data) to five (helicopter-based data) points per $m^{2}$. Outliers such as extremely large snow depths were masked and negative snow depths were set to zero. The ALS data sets analysed in this study, and how they were processed is comprehensively described in Grünewald et al. (2013). A detailed review on ALS for snow cover observations has recently been published by Deems et al. (2013).

\subsection{Airborne digital photogrammetry (ADP)}

Digital photogrammetry (ADP) is a remote sensing technology that is applied to acquire high resolution DSMs by exploiting photogrammetric image correlation techniques (Maune, 2001). Identical to ALS, snow depth maps can be calculated by subtracting a summer DSM from a winter DSM.
The Leica Geosystems Airborne Digital Sensor ADS80 is an opto-electronic line scanner, mounted on an aeroplane, that is able to simultaneously acquire four spectral bands (red, green, blue and near infrared) with a radiometric resolution of 12 bits from three different viewing angles $\left(-16^{\circ}\right.$, $0^{\circ}$ and $27^{\circ}$ ). GNSS/IMU-supported orientation of the image strips supplemented by the use of ground control points achieved a horizontal accuracy of 1-2 ground sampling distances $(0.25-0.5 \mathrm{~m})$. For photogrammetric DSM generation we use the "adaptive automatic terrain extraction" (ATE) system as part of the SOCETSET software version 5.4.1 from BAE SYSTEMS. After image orientation this state of the art software is used for point matching, point cloud generation and gridding of the final DSM raster. The point clouds had an average point density of about five points per square metre and were then averaged to a regular grid of $2 \mathrm{~m}$ (Bühler et al., 2014). Areas covered by forests, bushes and buildings as well as identified outliers are masked out prior to the snow depth map generation, because the reliability of the DSM is substantially reduced in those areas.

The sensor had already been successfully used to detect avalanche deposits in the area of Davos (Bühler et al., 2009) and is more economic for large-scale data acquisition than ALS due to higher flight altitude and therefore reduced flight time. More detailed information on the Leica ADS optoelectronic scanner can be found in Sandau (2010).

Bühler et al. (2014) compared the ADS snow depth maps with different independent snow depth measurements. They find RMSE values of less than $30 \mathrm{~cm}$ in areas above tree line. The RMSE values strongly depend on the distance of the sensor from the ground which reduces the accuracy of snow depth to less than $50 \mathrm{~cm}$ at the valley bottom (highest distances). Moreover, Bühler et al. (2012) found that the quality of the data is limited by the steepness of the terrain. They state that data gathered in slopes steeper than $50^{\circ}$ might be affected by large potential biases.

\section{Study sites}

Figure 1 presents an overview map of the data sets analysed in this study. Basic descriptions and some summary statistics on topography and snow cover of the seven investigation areas are provided in Table 2. Apart from the ADP-data, the data sets analysed in this study are the same as in Grünewald et al. (2013). We are therefore only proving a very short overview on each of the study sites and summarise their similarities and differences in the last paragraph. All data sets had been gathered approximately at the time of the local maximum of the seasonal snow accumulation (Table 1) and reflect the cumulative snow fall of the respective accumulation season.

A large data set has been collected by ADP for the district of Davos in the eastern part of the Swiss Alps on 3 September 2013 and 20 March 2012 (Fig. 2). In total, an area 
Table 1. Data sets analysed in the study where "Date" refers to the date of the winter survey, "Mean acc." to the mean accuracy in vertical direction as denoted in the reference column and "Platform" to the measurement platform.

\begin{tabular}{|c|c|c|c|c|}
\hline Name & Date & Mean acc. $[\mathrm{m}]$ & Platform & Reference \\
\hline Dischma valley (DIS) & 20 March 2012 & $0.3-0.5$ & Leica ADS80 & Biibler et al (2009 2014) \\
\hline Strela (STRE) & & & & \\
\hline Val de Núria (NUR) & 9 March 2009 & 0.3 & Optech ALTM3025 & \\
\hline Hintereisferner (HEF) & 7 May 2002 & 0.3 & Optech ALTM1225 & $\begin{array}{l}\text { Moreno Baños et al. (2009) } \\
\text { Geist and Stötter (2008); Bollmann } \\
\text { et al. (2011) }\end{array}$ \\
\hline Haut Glacier d'Arolla (ARO) & 1 May 2007 & 0.1 & Riegl LMS Q240i-60 & \\
\hline Wannengrat (WAN) & 9 April 2009 & 0.1 & Riegl LMS Q240i-60 & Dadic et al. $(2010 \mathrm{a}, \mathrm{b})$ \\
\hline & & & & $\begin{array}{l}\text { Grünewald and Lehning (2011); } \\
\text { Lehning et al. (2011) }\end{array}$ \\
\hline Piz Lagrev (LAG) & 7 April 2009 & 0.1 & $\begin{array}{l}\text { Rieg1 LMS Q240i-60 } \\
\text { (helicopter) }\end{array}$ & $\begin{array}{l}\text { Grünewald and Lehning (2011); } \\
\text { Lehning et al. (2011) }\end{array}$ \\
\hline
\end{tabular}

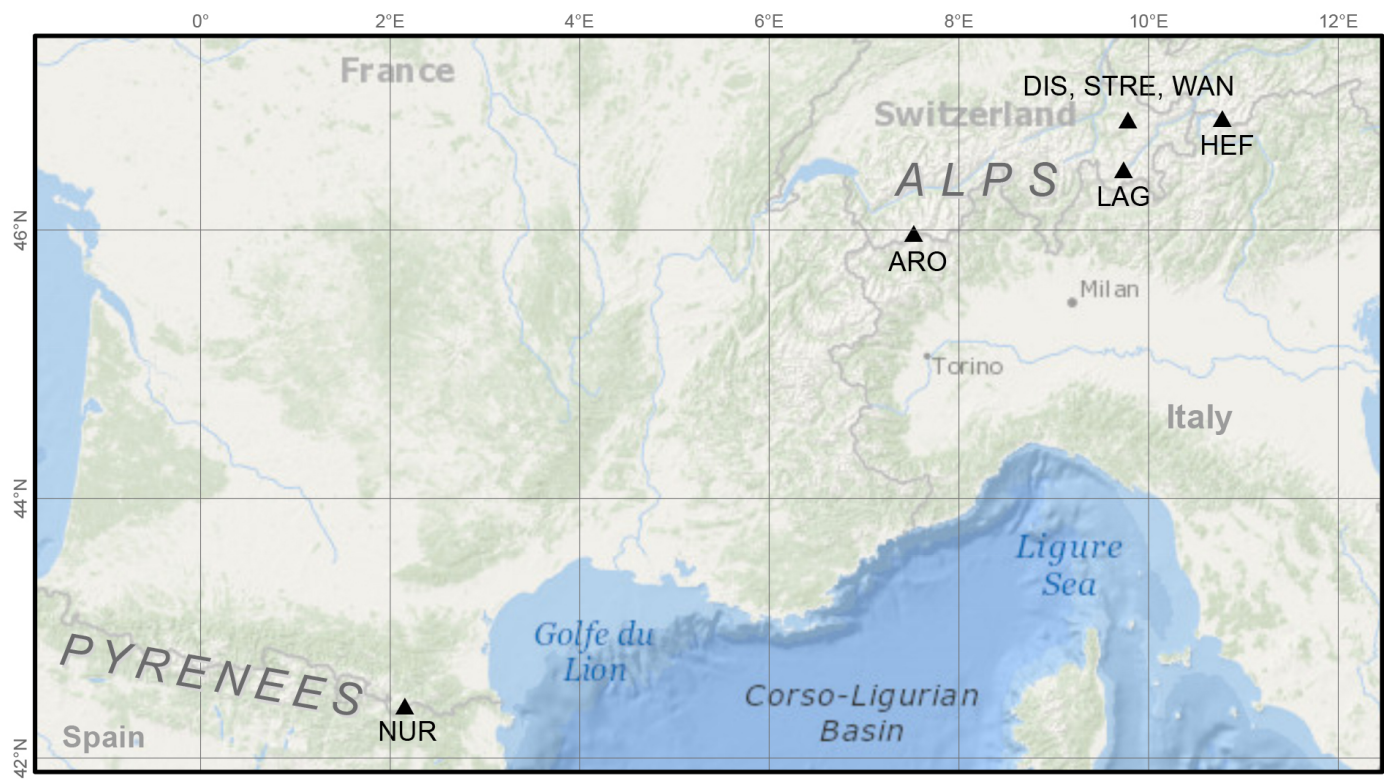

Figure 1. Location of the study sites Val de Núria (NUR), Haut Glacier d'Arolla (ARO), Dischma valley (DIS), Strela (STRE), Wannengrat (WAN), Hintereisferner (HEF) and Piz Lagrev (LAG). Basemap: Esri, GEBCO, NOAA, National Geographic, DeLorme, HERE, Geonames.org, and other contributors, reproduced with permission of Esri.

of $124 \mathrm{~km}^{2}$, consisting of 12 overlapping image strips (approx. $70 \%$ overlap across track), has been covered in the surveys. The ground sampling distance of the imagery is about $25 \mathrm{~cm}$, limited through the minimal flying height for high alpine terrain (Bühler et al., 2012).

The data set was split into two study sites. The Strela data set (STRE) covers a large section of the mountain range located in the north-western area of the Landwasser valley (Figs. 2, 3c). The mountain range spans from south-west to north-east and is perpendicular to the main wind that is typ- ically from the north-west (Schirmer et al., 2011). Northern and southern aspects are dominant in the data. The terrain is a mixture of alpine slopes with varying steepness. Rocky outcrops and some larger rock faces are present, especially in the summit regions. Note that the Wannengrat data set (WAN) is a small subsection in the centre of STRE. However the year of the survey and the sensor obtained for the data collection differ (Table 1).

The second study site in the region of Davos is the Dischma valley (DIS) in the east of the town of Davos 
Table 2. Summary statistics and main characteristics of the investigation areas: "Area" is given in $\mathrm{km}^{2}$, elevation range (EL) in m a.s.1., mean slope (SL) in ${ }^{\circ}$, mean and standard deviation (SD) of snow depth (HS) in $\mathrm{m}$. Areas with trees and larger vegetation were masked from the data sets.

\begin{tabular}{|c|c|c|c|c|c|c|c|c|}
\hline Name & Location & Area & Elev & SL & Asp & mean HS & std HS & Description \\
\hline DIS & $\begin{array}{l}\text { Davos, eastern } \\
\text { Swiss Alps }\end{array}$ & 71 & $1710-3146$ & 29 & All & 1.37 & 0.95 & $\begin{array}{l}\text { Mixture of steep and gentle } \\
\text { slopes, some rock faces }\end{array}$ \\
\hline STRE & $\begin{array}{l}\text { Davos, eastern } \\
\text { Swiss Alps }\end{array}$ & 26 & $1850-2781$ & 29 & All & 1.77 & 1.46 & $\begin{array}{l}\text { Mixture of steep and gentle } \\
\text { slopes, some rock faces }\end{array}$ \\
\hline NUR & $\begin{array}{l}\text { South-eastern } \\
\text { Spanish Pyrenees }\end{array}$ & 28 & 1910-2910 & 28 & All & 1.05 & 1.06 & $\begin{array}{l}\text { Mixture of gentle slopes } \\
\text { and some rock outcrops }\end{array}$ \\
\hline HEF & $\begin{array}{l}\text { Rofen valley, south- } \\
\text { western Austrian Alps }\end{array}$ & 25 & $2370-3739$ & 24 & All & 2.09 & 1.2 & $\begin{array}{l}50 \% \text { glaciers, steep talus } \\
\text { and rock faces }\end{array}$ \\
\hline ARO & $\begin{array}{l}\text { Valais, south-western } \\
\text { Swiss Alps }\end{array}$ & 10 & $2400-3550$ & 28 & SW to SE & 1.14 & 0.9 & $\begin{array}{l}50 \% \text { glaciers, steep } \\
\text { talus and rock faces }\end{array}$ \\
\hline WAN & $\begin{array}{l}\text { Davos, eastern } \\
\text { Swiss Alps }\end{array}$ & 4 & $1930-2658$ & 27 & All & 1.48 & 1.07 & $\begin{array}{l}\text { Mainly talus slopes, some rocky outcrops } \\
\text { and rock faces in the summit region }\end{array}$ \\
\hline LAG & $\begin{array}{l}\text { Engadine valley, south-eastern } \\
\text { Swiss Alps }\end{array}$ & 3 & 2070-3084 & 40 & SE to SW & 1.56 & 1.41 & $\begin{array}{l}\text { Steep talus slopes } \\
\text { surrounded by rock faces }\end{array}$ \\
\hline
\end{tabular}

(Fig. 2, 3a). The $13 \mathrm{~km}$ long valley extends parallel to the main flow from the north-west to the south-east. The data set is not only consisting of the eastern and western slopes of the Dischma valley, but also includes the upper flanks of the two neighbouring valleys. The land cover is similar to STRE but easterly and westerly aspects dominate. The summer (no snow) data set is from September 2013 and the winter survey from March 2012. As we cannot account for potential changes of the glacier surface in summer that could bias the snow depth on the glaciers, we removed the two small glaciers in the highest elevation of the site.

This large data set is supplemented by the smaller, ALSbased data sets presented by Grünewald et al. (2013) (Tables 1, 2). The first study site, the Piz Lagrev (LAG) is a steep, south-facing mountain slope in the Engadine valley in the south-east of Switzerland. The area is dominated by steep rock faces and two rather flat bowls where most of the snow accumulates. The second site, the Haut Glacier d'Arolla (ARO) is located in the western part of the Swiss Alps. About half of the site is covered by glaciers. The remaining areas are rather steep talus slope and rock faces. The characteristics of the Hintereisferner (HEF) study domain in the Öztal Alps of south-western Austria are similar to ARO. Steep talus slopes and rock faces dominate the valley flanks, and about $50 \%$ of the domain is glaciated. The last study site analysed in this paper is the Vall de Núria (NUR) located at the main divide of the eastern Spanish Pyrenees. Slopes of diverse steepness with some rocky outcrops near the summit level are typical of this $28 \mathrm{~km}^{2}$ data set.

Most of the sites are similar in terms of climatic and topographic conditions. All data sets from the Alps are located at or near to the main divide but the dominant synoptic conditions differ. HEF, WAN, STRE and DIS are mostly influenced by storms from the north-west while LAG and ARO are dominated by south-westerly flows. NUR is also dominated by synoptic flow from the north-west but the climate is
Mediterranean with high variability in precipitation, higher temperatures and insolation. The largest portions of all study sites (including NUR) belong to the high-alpine zone and elevations are above $1700 \mathrm{~m}$ a.s.l. for all study sites. Forests only exist in the lowest elevation bands and have been masked. Rocky outcrops and rock faces are present in all study sites but the occurrence and their frequency varies spatially. In general, the higher elevations appear steeper and rougher than the lower parts of the study sites. Finally, ARO and HEF discriminate against the other sites by their large glaciers.

\section{Methods}

This study analyses elevation dependencies of snow depth at three different scales. Firstly, regional characteristics are assessed by calculating gradients for the complete data sets listed in Tables 1 and 2. Secondly, we subdivided the data into smaller sub-catchments ( 1 to $5 \mathrm{~km}^{2}$ ) as shown in Figs. 2 and 3a,c. This gives a measure of the variability. To assess the scale of single mountain slopes, we manually defined $100 \mathrm{~m}$ wide transects (Figs. 2, 3). These transects extend perpendicular to the slope and span the entire difference in altitude of the respective mountain slopes.

Similar as in Grünewald and Lehning (2011), the subareas were subdivided into $100 \mathrm{~m}$ elevation bands and the mean snow depth was calculated for each subarea and each elevation zone. To avoid values that are based on a very small number of cells, elevation zones that had less than $0.5 \%$ of the total number of cells of the specific sub-catchment or transect were removed. The mean snow depths were then plotted against their respective elevation level and classified according to their general shape. Based on a first visual analysis we identified a set of typical shapes of gradients as indicated in Fig. 4 and discussed below. For all curves that were characterised by a distinctive peak (Fig. 4 shape A and B), 


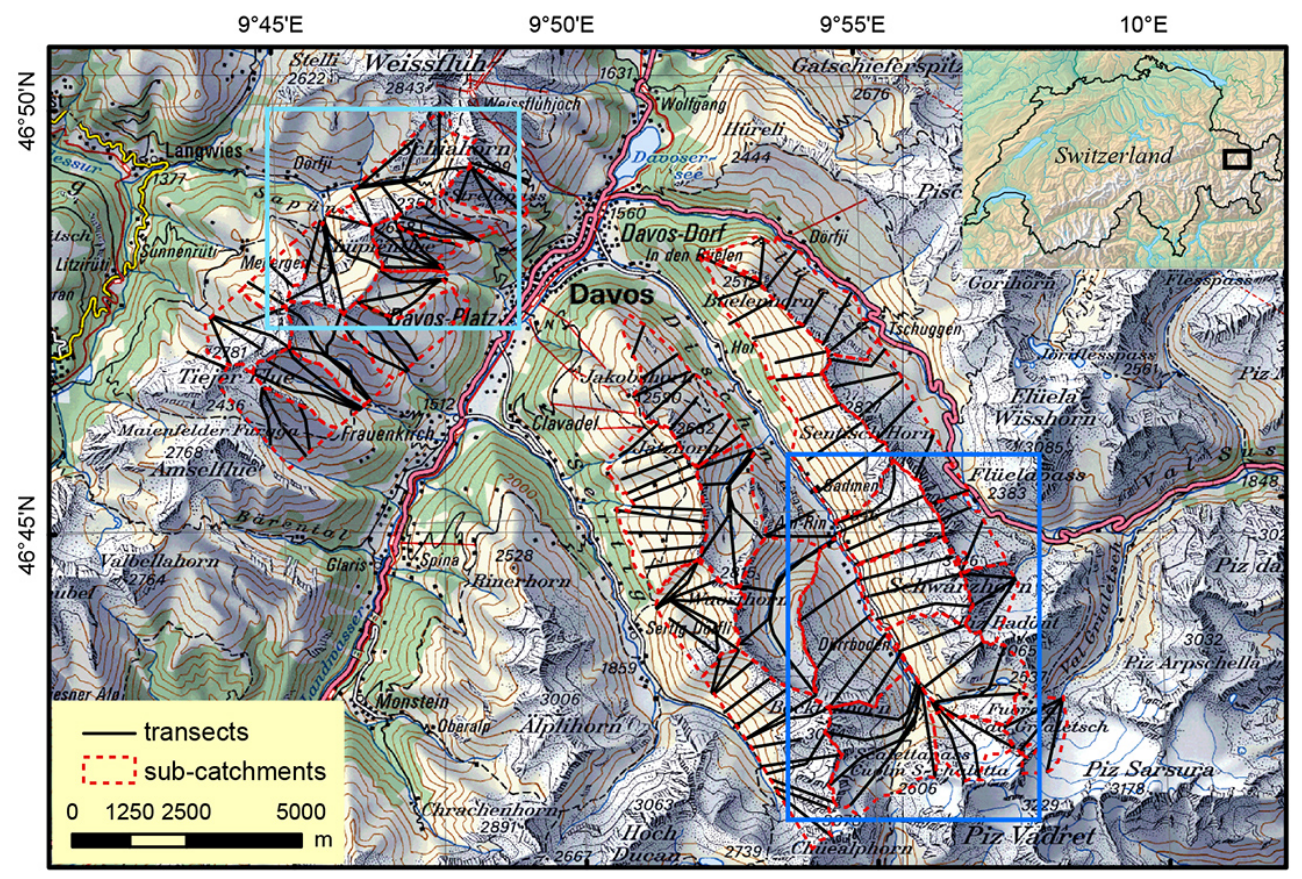

Figure 2. Overview map on the study region DIS and STRE. The upper left panel indicates the position in the east of Switzerland. Detailed views for parts of the domains are shown in Fig. 3. Maps reproduced with permission (Swisstopo, JA100118).

that reflects a local maximum of the elevation-snow depth relationship, the elevation level of this peak could be assigned.

A visual examination of the location of the peak in relation to the topography of the subarea suggests a possible correlation with the elevation level of rocky outcrops (level of rocks). The lower elevation levels of such rocky sections were therefore, where present, subjectively identified. We analysed topographic maps (scale 1:25000 or 1:50000) and hillshade images of the summer DSM (resolution $1 \mathrm{~m}$ ) of each area of interest (transect or sub-catchment). The combination of map and hillshade provides a good indication of the small scale topography and enables to manually detect areas with rock signature (maps) or obvious rock structure (hillshades). The respective elevation level is then rounded to the nearest $50 \mathrm{~m}$ contour line. Figure $3 \mathrm{~b}$ and d show examples of the level of rocks as identified for the transects TD1, TD2 and TS2. In TS3 no major rocks are present and therefore no level of rocks was detected.

The procedure works well for transects but is rather vague at the scales, where large areas are included in each elevation zone. This leads to large potential scatter of the level of rocks. While relatively clear levels could be detected for most slope transects, the rocky sections already varied strongly for the sub-catchments. At the scale of entire valleys or mountain ranges (data sets), the even larger diversity fully prevents an identification of a single rock level. Moreover, it needs to be noted that such rocky sections were not present for all subareas. For the subareas that featured both, a peak and a clear level of rock, we finally created scatter plots and correlation analysis. This was on one hand performed for each of the study areas separately, and on the other hand for the comprehensive data set.

\section{Results}

\subsection{General shape of gradients}

Figure 4 indicates idealised shapes of the elevation-snow depth relationships as qualitatively detected from the data (Figs. 5, 6, 7). The most prominent shape is shown in panel A of Fig. 4: the curve increases up to a specific elevation level where it peaks and finally decreases in the remaining elevation bands. Note that this shape is an oversimplification that only aims to picture the main characteristics of the general shapes. The slope is not necessarily steady, several smaller spikes and peaks might be present and the peak of the gradient can be flat and span several elevation bands. Figures 5 to 7 are examples for the variability of the single shapes.

Panels B to E of Fig. 4 illustrate variations of type A. Type $\mathrm{B}$ is principally identical to A but is additionally characterised by a dominant snow depth maximum in the lowest elevations. Such maxima are caused by local accumulation zones such as snow filled ditches or avalanche deposits. A distinctive secondary maximum is always present in class B. For the analysis presented in Sect. 5.6, this secondary maximum is treated as peak of the elevation-snow depth relationship. Gradients classified as type $\mathrm{C}$ to $\mathrm{E}$ do not show distinctive peaks. $\mathrm{C}$ is similar to $\mathrm{B}$ but a decrease of snow depth 


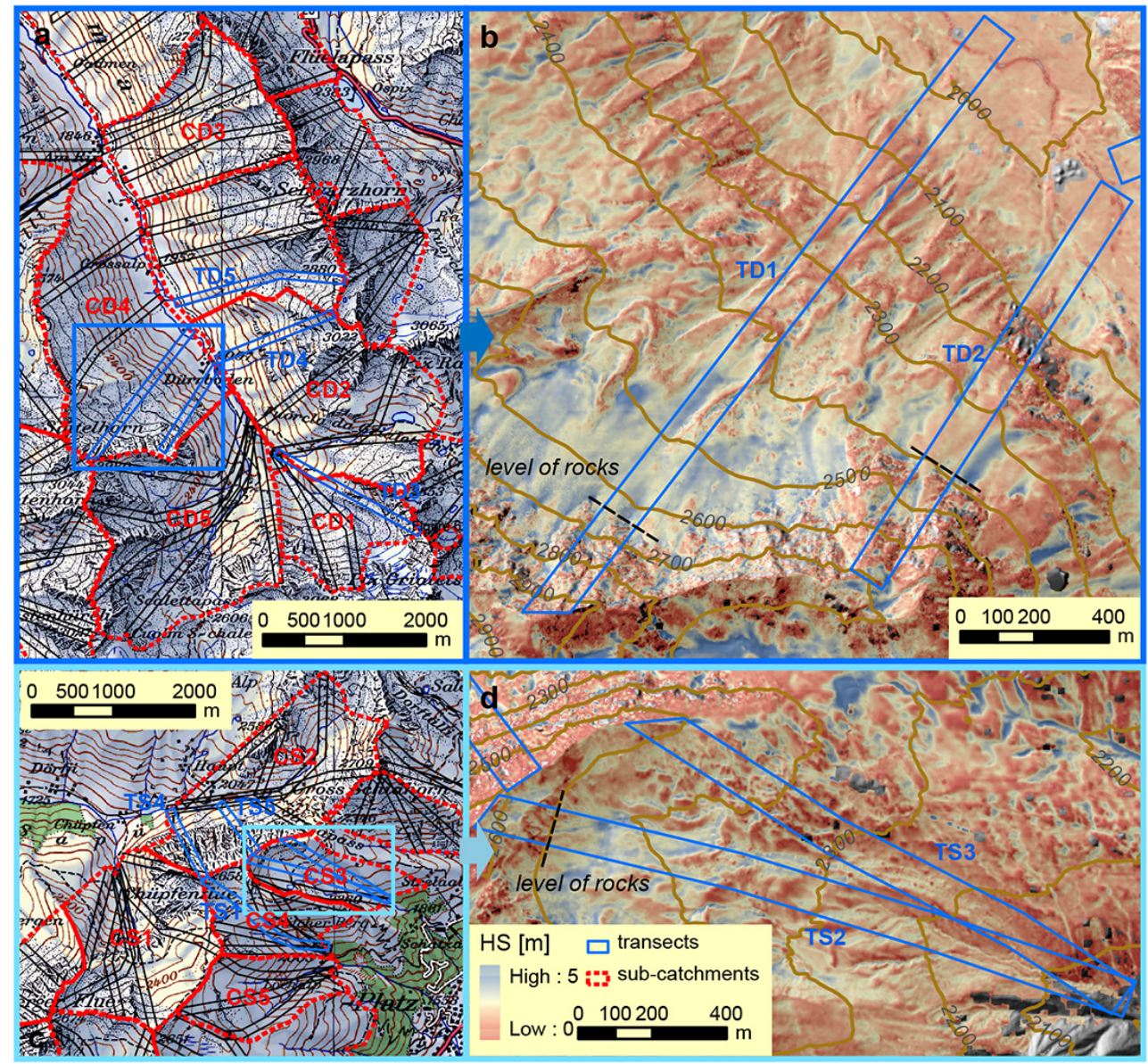

Figure 3. Detailed maps of catchment (CD1-5 and CS1-5 see Fig. 6), and transects (CT1-5 and CS 1-5 see Fig. 7) and discussed in the text. Maps reproduced with permission (Swisstopo, JA100118).

in the higher elevations is missing. Shape D and E present steady positive (D) or negative (E) gradients with no clear maximum. These variations are attributed to processes in the discussion below.

Figure 5a presents elevation gradients of snow depth at the scale of the complete data sets. For Fig. 5b, the curves were normalised according to

$\widetilde{X}=\frac{X-\min (X)}{\max (X)-\min (X)}$,

where $\tilde{X}$ represents the scaled variable (snow depth or elevation).

\subsection{Gradients: complete sets}

At the scale of the complete data sets, we only detected type A gradients (Fig. 5). This shape is evident for the raw data (Fig. 5a) and the curves show a striking collapse in the rescaled data (Fig. 5b). All data sets show a clear increase of snow depth with elevation followed by a pronounced maximum and a more or less definitive decrease. Even though the general shape appears similar, the location of the maximum and the gradient appear variable between the study sites.

\subsection{Gradients: sub-catchment}

Figure 6 presents curves for five selected sub-catchments for STRE (Fig. 6a) and DIS (Fig. 6b), respectively. The locations of the sub-catchments are indicated in Fig. 3. Most of the curves can be classified as type A (CS1, CS3, and CD2 to 5 ) but the shapes are more variable than on the scale of the complete data sets (Fig. 5). Mean snow depths are clearly increasing with elevation and reach pronounced peaks at a certain level.

CS2, CS4, CS5 and CD1 are representative for type B gradients: a maximum in the lowest elevation band is followed by a short negative trend and a steady increase culminating in a distinct peak. The maxima at the low elevation bands are attributed to snow filled ditches that dominate the largest portion of the lowest elevation bands. The combination of a relatively small area of the elevation zone (in comparison to the other zones of the sub-catchments) with snow depths of more than $5 \mathrm{~m}$ in the gullies explains the low maxima for CS4 and 

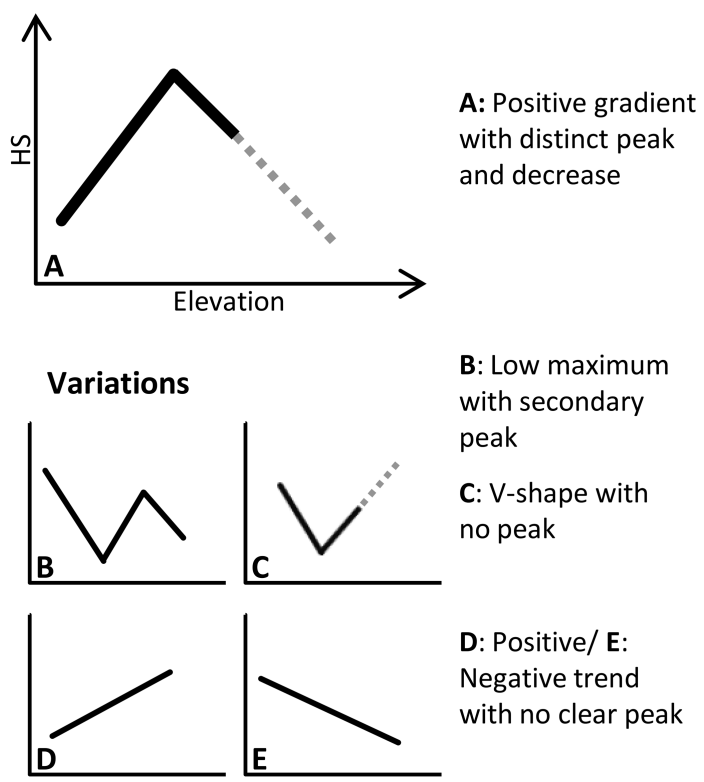

Figure 4. Idealised shape of elevation gradients and variations as identified from the data sets.

CS5. The accumulation zone in and around a ditch in CS2, with snow depths around $2 \mathrm{~m}$, is clearly less pronounced than those in CS4 and CS5. However, this small area of snow accumulation is still enough for the slight maximum in comparison to the shallower snow depth in the higher elevation zones. The extreme snow depths in CD1 are caused by the deposition of large snow drifts in a terrain depression at the foot of the steep northern slopes. This accumulation zone is covering the vast part of the two lower elevation bands and snow depths of more than $8 \mathrm{~m}$ could be detected. Depositions of similar dimensions are also present in some of the higher elevation bands. However, they do not cover such large portions of the area as in the lower section. This results in the clearly reduced mean values and in the decreasing trend of the grey curve (CD1) in Fig. 6b. Above the low-elevation maxima typical type A shapes are evident for CS2, CS4, CS5 and CD1.

\subsection{Gradients: slope-transects}

Figure 7 displays identical relations as Fig. 6 but for transects instead of sub-catchments. The shapes of the curves show a higher variability in Fig. 7 than those in Figs. 5 and 6. This is because the smaller support areas of each elevation band provoke larger effects of the small scale variability in snow depth on the shape of the curves. In contrast, this small scale heterogeneity is rather smoothed out for the sub-catchment (Fig. 6) or the complete data sets (Fig. 5). However, the principal findings are also visible for the transects. Most of the curves can be classified as type A (TS2, TS3, TS4, TS5, TD1, TD2, TD3, TD5). TS2 displays a nearly ideal type A (Fig. 4) curve with a linear increase, followed by a marked snow
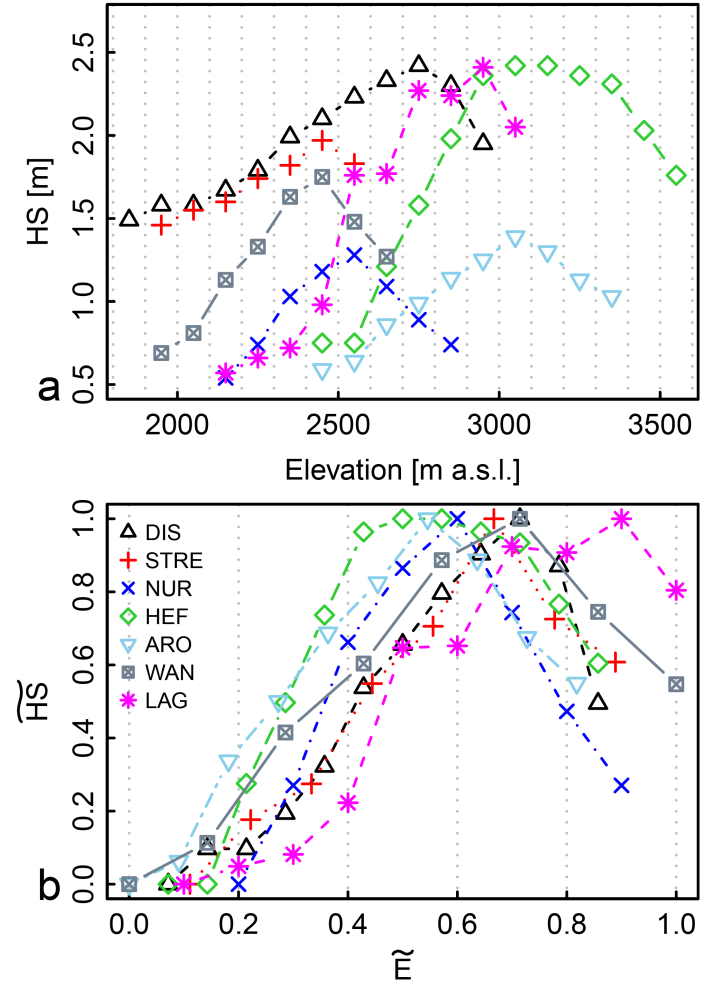

Figure 5. Elevation gradients on the scale of the complete data sets. In (a) snow depths are plotted against Elevation as raw values (b) and re-scaled by applying Eq. () to snow depth and elevation.

depth maximum at $2450 \mathrm{~m}$. Contrary to that, the maximum of TS3 appears less pronounced. The detailed map of the two transects (Fig. 3d) provides insight into the snow cover characteristics that cause the respective curves. Little snow in the lower sections, the location of the maxima in the flat bowls and the decrease of snow depth in the steep, rocky slopes at the highest elevations are clearly visible. A second detailed map is illustrated in Fig. 3b for TD1 and TD2. Again, the pronounced peaks and the distinct decrease of snow in the steep rock bands at the top levels are well illustrated. The curve with the most extreme maximum is represented by TS4 (Fig. 7a). While only little snow had been accumulated on the rock face itself, a large deposition zone is evident in the gentle slope at the foot of the rock face (Fig. 3c). Redistribution of snow due to gravitational forces might be the main cause for these extreme snow depth differences.

Different types of shape are only present for TS1 and TD4. TS1 represents a type B curve with a low peak, a distinctive minimum and a slight secondary peak in the higher elevation. The low maximum is attributed to a snow filled ditch in the lowest elevations and the secondary peak is caused by an accumulation zone in a gentle bowl below steep slopes at the top. TD4 has been classified as type D. The curve is characterised by predominately positive slopes with two smaller peaks and a maximum in the highest elevation zone. 

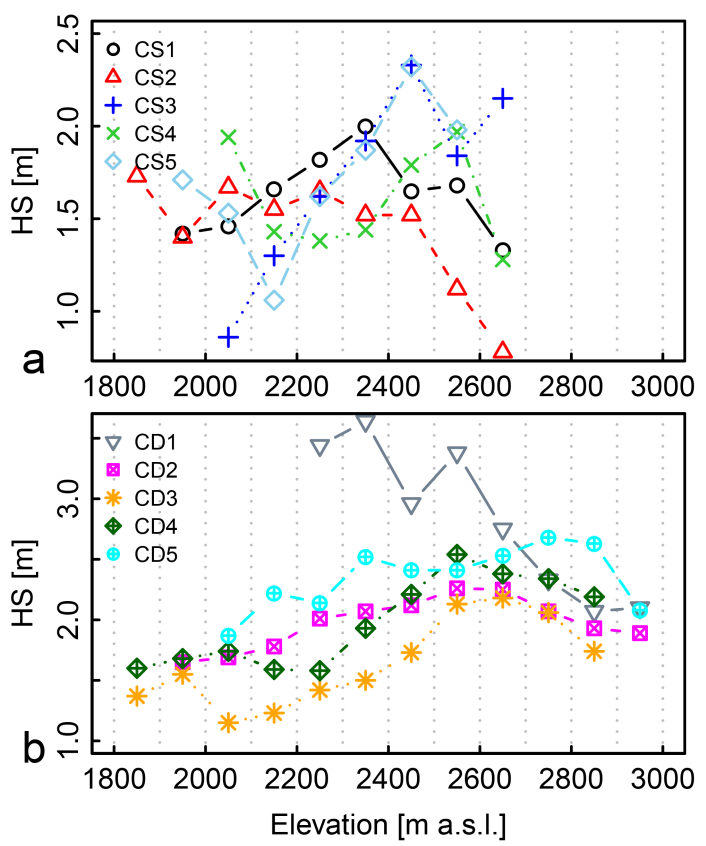

Figure 6. Elevation gradients of selected sub-catchments from the Strela mountain range (a) and the Dischma valley (b).

\subsection{Frequency of occurrence of gradient types}

Figure 8 summarises the number of subareas that have been assigned to the specific type of gradient for each data set. 67 to $100 \%$ of all gradients have been classified as type A for the sub-catchments of each specific study site (Fig. 8a). In total $79 \%$ of all sub-catchments belong to type A. Merging all gradients with a distinctive peak (type A and B) increases the portion to $93 \%$. All other types appear to be rare. Only one sub-catchment in DIS has been classified as type D and one as type E for NUR and STRE, respectively. A similar picture characterises the distribution of the gradient types at the scale of the transects (Fig. 8b). $72 \%$ of all transects (60 to $89 \%$ of each data set) belong to type A. Combining type A and B results in an increase to $79 \%$. Similar to Fig. 8a, the remaining types are very rare. Only type D (positive trend) curves are more frequent, at least for DIS and STRE.

\subsection{Relation of elevation gradients and topography}

In the previous sections, we showed that the vast majority of subareas feature distinctive maxima in their elevation-snow depth relationships. From this finding, the question whether the elevation level of this peak can be explained by the topographical settings of its respective location should be answered. Visual impression suggests that most of the maxima would be found below distinctive terrain breaks such as steep cliffs or slopes. We tried to automatically identify the elevation of the most dominant terrain break for each subarea by calculating the maximum slope of the relationship between
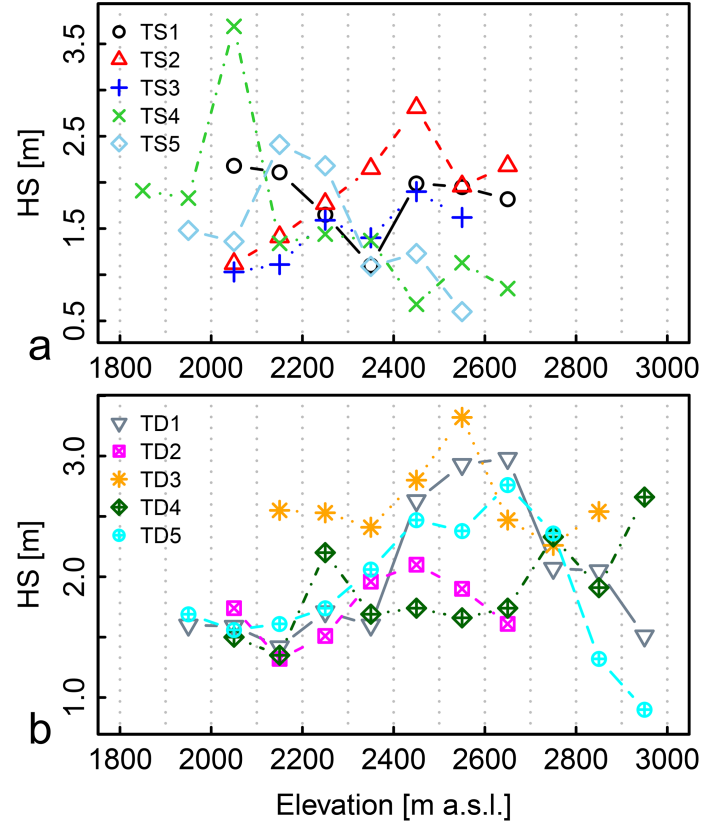

Figure 7. Elevation gradients of selected transects from the Strela mountain range (a) and the Dischma valley (b).

elevation and terrain slope or terrain roughness (expressed by the standard deviation of the slope), respectively. However, the topographical complexity of the terrain prevented an adequate identification of the appropriate elevation level. We also found (not shown) that only low correlation coefficients result between e.g. terrain roughness and the elevation levels of the maxima in snow depth. Following this, we manually identified the predominant level of rocks as described before.

A rock level was present for the majority of the subareas (transects: $70 \%$, sub-catchments: $71 \%$ ). In total, $67 \%$ of the sub-catchments and $58 \%$ of the transects feature both, a peak in the elevation-snow depth curves (Fig. 8 shape A and B) as well as a level of rocks.

Figure 9 illustrates scatter plots of the level of rocks versus the level of the maximum of the elevation-snow depth relationship. Especially for the transects (Fig. 9b) a clear linear relationship $\left(R^{2}=0.84\right)$ is visible. Such a correlation is present for each single data set and for the merged data. Figure $9 \mathrm{~b}$ also indicates that the vast majority of the points are shifted by about 50 to $200 \mathrm{~m}$ below the $1: 1$ line. Hence, the areas with the peak in the snow depths tend to be located below the level of rocks. This confirms the expectation that more snow accumulates in gentle slopes at the foot of steep slopes and rough terrain due to preferential deposition (Lehning et al., 2008) and redistribution of snow by sloughing, avalanching and wind drift. The two outliers for HEF (dark blue circles at the right side of Fig. 9b) are transects that span the entire glacier. Rocks are only present in the highest elevation bands. The snow depth maxima are located at ac- 

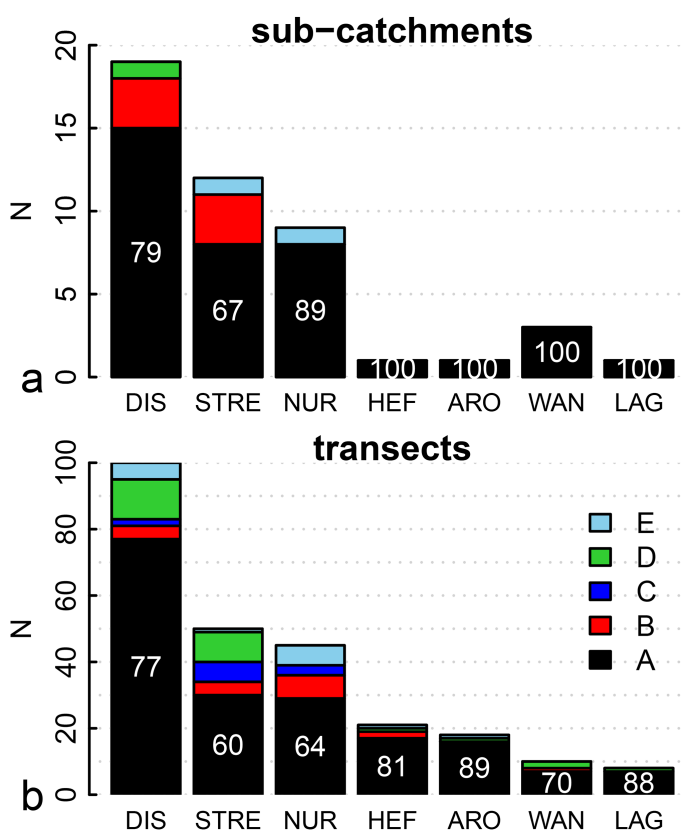

Figure 8. Frequency distribution of the types of gradients (A-B as shown in Fig. 4) for sub-catchments (a) and transects (b) of each data set. White numbers indicate the percentage of subareas classified as type A.

cumulation zones in the middle elevations of the glacier. A secondary, less pronounced peak was found below this rock band but is not visible in Fig. 9b. The two positive outliers of NUR (light blue circles at the left side of Fig. 9b) can also be explained by their specific topography. A small rock band is present in both transects, but the main peak in the elevationsnow depth relationship can be found in a flatter section on top of the rock face. Removing these four outliers would increase $R^{2}$ to 0.9 .

In contrast to Fig. 9b the correlation $\left(R^{2}=0.37\right)$ for the sub-catchments (Fig. 9a) - even though still highly significant - is much weaker. A downward shift as notified for the transects is not evident. As described before, the reason for this reduced correlation is probably that the level of rock cannot be clearly detected for such large areas. Moreover, the mean snow depths in each elevation band rather reflect the average of large areas with variable topography and not of a clearly differentiated terrain unit as for the transects. In combination, this higher variability counteracts the predictability of the location of the peak.

\section{Discussion}

We have shown that the clear majority of subareas are characterised by positive elevation gradients of snow depth with distinct peaks at a certain level. This finding is valid for all investigation areas and at all scales, even though the effect was less universal for smaller subareas (transects). We sug- gest that this shape is attributed to a positive elevation gradient of precipitation that is modified by the interaction of the snow cover with the local terrain. Processes that reshape the precipitation distribution near the surface and the snow accumulation at the ground are first the preferential deposition of precipitation in sheltered areas and second the redistribution of snow by wind and gravity. These processes result in a relocation of snow from steep and exposed areas to rather sheltered gentle slopes in lower elevations. Such steep, exposed and frequently rocky areas are usually located in the highest elevations (at least for the data sets analysed in this study). This interpretation is well confirmed by our results.

The shape of orographic precipitation is also affected by other physical processes. Roe and Baker (2006) specify cloud microphysics (e.g. condensation rate, growth time and advection of hydrometeors, evaporation), mountain geometry and characteristics of the air flow as drivers for variations of orographic precipitation. In a model study they found that the interaction of these processes might result in strong spatial and temporal variability of elevation gradients of precipitation rates and consequently affect the location of the maximum precipitation rate. Furthermore, owing to the ClausiusClapeyron effect, the decreasing density of the air results in a strong reduction of moisture available for condensation. At a certain elevation level, this effect can be expected to outbalance the increase in precipitation caused by the temperature decrease with elevation (Burns, 1953; Alpert, 1986; Roe and Baker, 2006). Following such considerations, Havlik (1969) expected such a precipitation maximum above $3500 \mathrm{~m}$ a.s.1. for the Alps. In a model study where orographic precipitation was approximated solely based on moisture convergence, Alpert (1986) calculated a theoretical upper limit of the precipitation maximum for a bell-shaped mountain at an elevation of $3800 \mathrm{~m}$. However, in their case studies, the level varied strongly dependent on lapse rate, mountain height and mountain geometry and was at $2500 \mathrm{~m}$ for an adiabatic lapse rate and a mountain geometry typical for the Himalayas. Following good agreement of their results with observations, Alpert (1986) suggested that detailed microphysical processes appear less important to model orographic precipitation on high mountains.

A similar level of $3300 \mathrm{~m}$ a.s.l. was identified by Kirchner et al. (2014) as elevation of the maximum snow depth in their study site in the Sierra Nevada. They suggest that the flatter topography in these elevations of their domain reduced lifting and precipitation. Additionally, they name the exhaustion of perceptible water in the clouds as explanation for the lower snow depths beyond this level. However, in our data sets the level of the peak snow depth and the consecutive decrease are significantly lower (Figure 5a). Besides that, only very small areas in HEF and ARO are above such high elevations. We therefore believe that the impact of these processes is rather minor and that redistribution processes of snow are the main causes for these specific snow distributions. 


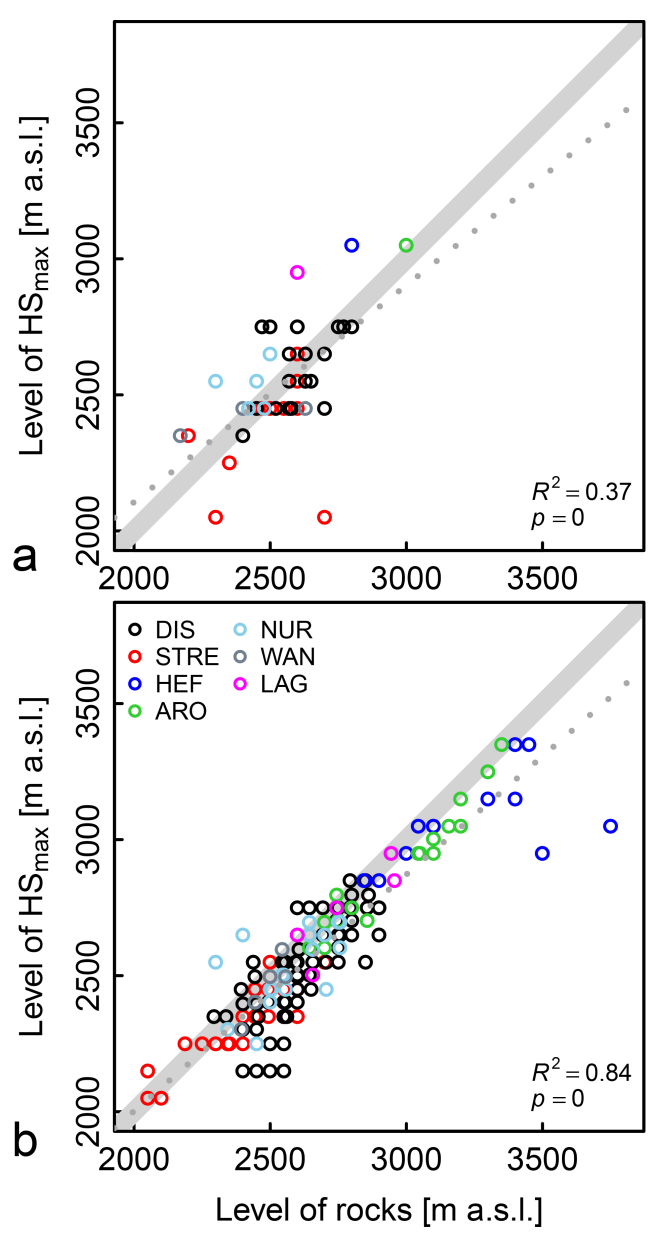

Figure 9. Level of rocks versus level of the maximum of the elevation-snow depth relationship for the sub-catchments (a) and the transects (b). The grey shaded area illustrates the 1:1 line $( \pm 50 \mathrm{~m})$ and the dashed line the linear fit of the merged data.

Our results refine important findings from earlier studies. Most of them reported on positive gradients of precipitation (e.g. Spreen, 1947; Peck and Brown, 1962; Frei and Schär, 1998; Blumer, 1994; Johnson and Hanson, 1995; Liu et al., 2011; Asaoka and Kominami, 2012) and snow (e.g. Rohrer et al., 1994; Bavera and De Michele, 2009; Lopez-Moreno and Stähli, 2008; Grünewald and Lehning, 2011; Lehning et al., 2011; Grünewald et al., 2013). Our data set from seven different mountain sites allows us to show for the first time how frequent the characteristic shape with a pronounced maximum snow depth at a certain elevation can be found. Nevertheless, we also show that the elevation-snow depth relation can vary significantly even across small distances and that areas of negative gradients exist. Such variability had also been postulated in earlier publications (e.g. Lauscher, 1976; Rohrer et al., 1994; Basist et al., 1994; Sevruk, 1997; Wastl and Zängl, 2008).

We acknowledge the previously mentioned limitation in reliability of the data in extremely steep slopes. This con- straint is especially affecting the ADP data (Bühler et al., 2012), but must also be considered for the ALS data, especially for HEF and NUR, that had been obtained on aeroplane-based platforms (Bollmann et al., 2011; Hopkinson et al., 2012). However, the relatively small portion of such steep slopes in the data strongly limits the influence of such cells on the presented analysis. Only about $5 \%$ of the cells in DIS, STRE and HEF (and $2 \%$ of NUR) are steeper than $50^{\circ}$ and less than $2 \%$ are steeper than $60^{\circ}$. For STRE and DIS, about one-third of these steep $\left(>50^{\circ}\right)$ cells had already been masked in the post-processing of the data. Following this, the reduced accuracy of extremely steep areas will only have a minor impact on the analysis of larger subareas (all of the data sets and sub-catchments). On the contrary, for transects, large portions of elevation bands that coincide with pronounced rock faces are present. However, a detailed examination of such sections did not yield any conspicuous outcome. As the results match our principal process understanding, we are confident that the findings are adequate, especially as the focus of the analysis is rather qualitative.

\section{Conclusions}

We present a detailed assessment of the relationship of snow depth and elevation. The analysis is based on an extensive, spatial continuous data set consisting of high resolution and high quality snow depth data from seven mountain sites in the European Alps and Spanish Pyrenees. All data sets were gathered near to the maximum of the winter accumulation of the respective site and year. The analysis is performed on three different scales that range from basins or mountain ranges (all of the data sets) to sub-catchments ( $\mathrm{km} \mathrm{scale)}$ and individual slope transects.

We show that a characteristic shape of the elevation-snow depth relation was evident for the majority of the subareas at all scales. Typically, snow depth increases with elevation up to a certain level where a distinct peak can be found. Following this maximum, the mean snow depth tends to significantly decrease for the highest elevations (type A in Fig. 4). At the mountain range scale, all data sets showed the characteristic type A curve. $79 \%$ of the sub-catchments and $72 \%$ of the transects belong to this type. Merging the two types that are characterised by a distinct peak (A and B) increases the portion to $93 \%$ for the sub-catchments and $79 \%$ for the transects. However, the detailed shapes of the gradients are still variable. Location and shape of the peak and the slope of the curves differ between the subareas but show a remarkable collapse when properly scaled. Curves that deviate from this general shape are sparse but present.

We attribute this typical shape to an increase of snow fall with elevation. Snow depths are reshaped by redistribution of snow by wind and gravitational forces. In combination, these processes determine the typical shape of the gradients. 
This interpretation is underlined by an examination of the topographical location of these peaks. This analysis showed that a high correlation between the elevation of the peak and, if present, the level of predominant rocks exists. For the transects, the maximum of the elevation-snow depth relationship tends to be located 50 to $200 \mathrm{~m}$ below the level of rocks.

The presented study is limited to alpine, non-vegetated terrain. However, we also expect positive elevation gradients in forested areas. It remains to be investigated if the specific shapes deviate from those found in alpine terrain. It is also important to note that this study is restricted to a handful of selected study sites and single dates in one single year. The transferability of the results to other years remains limited, even though several studies have identified a high temporal consistency of snow depth between different seasons (Deems et al., 2008; Schirmer et al., 2011; Helfricht et al., 2014). However, it may not be assumed that such a consistency is valid for all mountain sites. Moreover, we analysed snow depth data that reflect a cumulative snow record of an entire accumulation season. Elevation gradients of single precipitation events might deviate from the patterns averaged for a complete accumulation season. It remains to be investigated if the typical shapes of gradients found in our study are already reflected in single snow fall events, and how they assemble to the seasonal snow distribution. For practical applications our results suggest that a spatial interpolation of snow depths, solely based on a linear trend, appears inadequate. Such an approach results in large potential biases in the higher elevations. The levelling and decrease of snow depth in the high elevations needs to be accounted for. Even though a generalised function describing this relationship does not yet exist, the re-scaled curves presented in Fig. 5b provide indication what such a relation could look like.

Acknowledgements. First we want to thank J. Parajka and an anonymous reviewer for their constructive comments. They helped to improve the paper considerably. The Swiss National Foundation is acknowledged for partly funding this work. We furthermore thank all our colleagues who helped in various ways, especially $\mathrm{R}$. Mott, C. Marty, C. Ginzler and A. Schilling. Finally, we are grateful to all people and institutions who provided data, particularly, Leica Geosystems for the ADP data, the Amt für Wald und Naturgefahren Graubünden for financial support for the LAG and WAN data, I. Moreno Banos, P. Oller, J. Marturia (Institut Geologic de Catalunia) for the NUR data, H. Stötter (Institute for Geography, University of Innsbruck) for the HEF data and R. Dadic (Antarctic Research Centre, University of Wellington) and P. Burlando (Institute for Environmental Engineering, ETH Zurich) for the data sets from ARO.

Edited by: R. Brown

\section{References}

Alpert, P.: Mesoscale Indexing of the Distribution of Orographic Precipitation over High Mountains, J. Clim. Appl. Meteorol., 25, 532-545, doi:10.1175/15200450(1986)025<0532:miotdo>2.0.co;2, 1986.

Arakawa, O. and Kitoh, A.: Intercomparison of the relationship between precipitation and elevation among gridded precipitation datasets over the Asian summer monsoon region, Global Environ. Res, 15, 109-118, 2011.

Asaoka, Y. and Kominami, Y.: Spatial snowfall distribution in mountainous areas estimated with a snow model and satellite remote sensing, Hydrol. Res. Lett., 6, 1-6, 2012.

Basist, A., Bell, G. D., and Meentemeyer, V.: Statistical Relationships between Topography and Precipitation Patterns, J. Climate, 7, 1305-1315, doi:10.1175/15200442(1994)007<1305:srbtap>2.0.co;2, 1994.

Bavera, D. and De Michele, C.: Snow water equivalent estimation in the Mallero basin using snow gauge data and MODIS images and fieldwork validation, Hydrol Proc., 23, 1961-1972, doi:10.1002/hyp.7328, 2009.

Bernhardt, M. and Schulz, K.: SnowSlide: A simple routine for calculating gravitational snow transport, Geophys. Res. Lett., 37, doi:10.1029/2010g1043086, 2010.

Blanchet, J., Marty, C., and Lehning, M.: Extreme value statistics of snowfall in the Swiss Alpine region, Water Resour. Res., 45, 12, doi:10.1029/2009wr007916, 2009.

Blöschl, G.: Scaling issues in snow hydrology, Hydrol. Proc., 13, 2149-2175, 1999.

Blumer, F.: Höhenabhängigkeit des Niederschlags im Alpenraum, Ph.D. thesis, 1994.

Bollmann, E., Sailer, R., Briese, C., Stotter, J., and Fritzmann, P.: Potential of airborne laser scanning for geomorphologic feature and process detection and quantifications in high alpine mountains, Zeitschrift für Geomorphologie, 55, 83-104, doi:10.1127/0372-8854/2011/0055s2-0047, 2011.

Bühler, Y., Hüni, A., Christen, M., Meister, R., and Kellenberger, T.: Automated detection and mapping of avalanche deposits using airborne optical remote sensing data, Cold Regions Sci. Technol., 57, 99-106, doi:10.1016/j.coldregions.2009.02.007, 2009.

Bühler, Y., Marty, M., and Ginzler, C.: High Resolution DEM Generation in High-Alpine Terrain Using Airborne Remote Sensing Techniques, Transactions in GIS, 16, 635-647, doi:10.1111/j.1467-9671.2012.01331.x, 2012.

Bühler, Y., Marty, M., Egli, L., Veitinger, J., Jonas, T., Thee, P., and Ginzler, C.: Spatially continuous mapping of snow depth in high alpine catchments using digital photogrammetry, The Cryosphere Discuss., 2014.

Burns, J. I.: Small-scale topographic effects on precipitation distribution in San Dimas experimental forest, Eos, Trans. Am. Geophys. Union, 34, 761-768, doi:10.1029/TR034i005p00761, 1953.

Carruthers, D. J. and Choularton, T. W.: A model of the feederseeder mechanism of orographic rain including stratification and wind-drift effects, Q. J. Roy. Meteor. Soc., 109, 575-588, doi:10.1002/qj.49710946109, 1983.

Colle, B. A.: Sensitivity of Orographic Precipitation to Changing Ambient Conditions and Terrain Geometries: An Idealized Modeling Perspective, J. Atmos. Sci., 61, 588-606, doi:10.1175/1520-0469(2004)061<0588: sooptc>2.0.co, 2004. 
Dadic, R., Mott, R., Lehning, M., and Burlando, P.: Wind influence on snow depth distribution and accumulation over glaciers, J. Geophys. Res.-Earth, 115, 8, doi:10.1029/2009JF001261, 2010a.

Dadic, R., Mott, R., Lehning, M., and Burlando, P.: Parameterization for wind-induced preferential deposition of snow, Hydrol. Proc., 24, 1994-2006, doi:10.1002/hyp.7776, 2010b.

Daly, C., Halbleib, M., Smith, J. I., Gibson, W. P., Doggett, M. K., Taylor, G. H., Curtis, J., and Pasteris, P. P.: Physiographically sensitive mapping of climatological temperature and precipitation across the conterminous United States, Int. J. Climatol., 28, 2031-2064, doi:10.1002/Joc.1688, 2008.

Deems, J. S. and Painter, T. H.: Lidar measurement of snow depth: Accuracy and error sources., Proceedings International Snow Science Workshop ISSW 2006, Telluride, CO, Proceedings International Snow Science Workshop ISSW, 384-391, 2006.

Deems, J. S., Fassnacht, S. R., and Elder, K. J.: Fractal Distribution of Snow Depth from Lidar Data, Journal of Hydrometeorology, 7, 285-297, 2006.

Deems, J. S., Fassnacht, S. R., and Elder, K. J.: Interannual Consistency in Fractal Snow Depth Patterns at Two Colorado Mountain Sites, Journal of Hydrometeorology, 9, 977-988, doi:10.1175/2008jhm901.1, 2008.

Deems, J. S., Painter, T. H., and Finnegan, D. C.: Lidar measurement of snow depth: a review, J. Glaciol., 59, 467-479, doi:10.3189/2013JoG12J154, 2013.

Durand, Y., Giraud, G., Laternser, M., Etchevers, P., Mèrindol, L., and Lesaffre, B.: Reanalysis of 47 Years of Climate in the French Alps (1958-2005): Climatology and Trends for Snow Cover, J. Appl. Meteorol. Clim., 48, 2487-2512, doi:10.1175/2009jamc1810.1, 2009.

Elder, K., Dozier, J., and Michaelsen, J.: Snow Accumulation and Distribution in an Alpine Watershed, Water Resour. Res., 27, 1541-1552, doi:10.1029/91wr00506, 1991.

Frei, C. and Schär, C.: A precipitation climatology of the Alps from high-resolution rain-gauge observations, Int. J. Climatol., 18, 873-900, 1998.

Gauer, P.: Numerical modeling of blowing and drifting snow in Alpine terrain, J. Glaciol., 47, 97-110, 2001.

Geist, T. and Stötter, J.: Documentation of glacier surface elevation change with multi-temporal airborne laser scanner data case study: Hintereisferner and Kesselwandferner, Tyrol, Austria., Zeitschrift für Gletscherkunde und Glazialgeologie, 41, 77106, 2008

Gruber, S.: A mass-conserving fast algorithm to parameterize gravitational transport and deposition using digital elevation models, Water Resour. Res., 43, W06 412, doi:10.1029/2006wr004868, 2007.

Grünewald, T. and Lehning, M.: Altitudinal dependency of snow amounts in two small alpine catchments: can catchment-wide snow amounts be estimated via single snow or precipitation stations?, Ann. Glaciol., 52, 153-158, 2011.

Grünewald, T. and Lehning, M.: Are flat-field snow depth measurements representative? A comparison of selected index sites with areal snow depth measurements at the small catchment scale, Hydrol. Proc., n/a-n/a, doi:10.1002/hyp.10295, 2014.

Grünewald, T., Schirmer, M., Mott, R., and Lehning, M.: Spatial and temporal variability of snow depth and ablation rates in a small mountain catchment, The Cryosphere, 4, 215-225, doi:10.5194/tc-4-215-2010, 2010.
Grünewald, T., Stötter, J., Pomeroy, J. W., Dadic, R., Moreno Baños, I., Marturià, J., Spross, M., Hopkinson, C., Burlando, P., and Lehning, M.: Statistical modelling of the snow depth distribution in open alpine terrain, Hydrol. Earth Syst. Sci., 17, 3005-3021, doi:10.5194/hess-17-3005-2013, 2013.

Havlik, D.: Die Höhenstufe maximaler Niederschlagssummen in den Westalpen, Freiburger Geographische Hefte, 7, 76, 1969.

Helfricht, K., Schöber, J., Schneider, K., Sailer, R., and Kuhn, M.: Inter-annual persistence of the seasonal snow cover in a glacierized catchment, J. Glaciol., 60, 889-904, doi:10.3189/2014JoG13J197, 2014.

Holko, L.: Evaluation of long-term snow cover data in a mountain catchment, Acta Hydrologica Slovaca, 1, 15, 2000.

Hopkinson, C., Sitar, M., Chasmer, L., and Treitz, P.: Mapping snowpack depth beneath forest canopies using airborne lidar, Photogramm. Eng. Rem. S., 70, 323-330, 2004.

Hopkinson, C., Collins, T., Anderson, A., Pomeroy, J., and Spooner, I.: Spatial Snow Depth Assessment Using LiDAR Transect Samples and Public GIS Data Layers in the Elbow River Watershed, Alberta, Can. Water Resour. J., 37, 69-87, doi:10.4296/cwrj3702893, 2012.

Houze, R. A.: Orographic effects on precipitating clouds, Rev. Geophys., 50, RG1001, doi:10.1029/2011rg000365, 2012.

Johnson, G. L. and Hanson, C. L.: Topographic and Atmospheric Influences on Precipitation Variability over a Mountainous Watershed, J. Appl. Meteorol., 34, 68-87, doi:10.1175/1520-045034.1.68, 1995.

Kerr, T., Clark, M., Hendrikx, J., and Anderson, B.: Snow distribution in a steep mid-latitude alpine catchment, Adv. Water Resour., 55, 17-24, doi:10.1016/j.advwatres.2012.12.010, 2013.

Kirchner, P. B., Bales, R. C., Molotch, N. P., Flanagan, J., and Guo, Q.: LiDAR measurement of seasonal snow accumulation along an elevation gradient in the southern Sierra Nevada, California, Hydrol. Earth Syst. Sci., 18, 4261-4275, doi:10.5194/hess-184261-2014, 2014.

Lauscher, F.: Weltweite Typen der Höhenabhängigkeit des Niederschlags, Wetter und Leben, 28, 80-90, 1976.

Lehning, M., Löwe, H., Ryser, M., and Raderschall, N.: Inhomogeneous precipitation distribution and snow transport in steep terrain, Water Resour. Res., 44, W07404, doi:10.1029/2007wr006545, 2008.

Lehning, M., Gruenewald, T., and Schirmer, M.: Mountain snow distribution governed by an altitudinal gradient and terrain roughness, Geophys. Res. Lett., 38, doi:10.1029/2011GL048927, 2011.

Liu, C., Ikeda, K., Thompson, G., Rasmussen, R., and Dudhia, J.: High-Resolution Simulations of Wintertime Precipitation in the Colorado Headwaters Region: Sensitivity to Physics Parameterizations, Monthly Weather Rev., 139, 3533-3553, doi:10.1175/mwr-d-11-00009.1, 2011.

Lopez-Moreno, J. I. and Stähli, M.: Statistical analysis of the snow cover variability in a subalpine watershed: Assessing the role of topography and forest, interactions, J. Hydrol., 348, 379-394, doi:10.1016/j.jhydrol.2007.10.018, 2008.

Maune, D.: Digital Elevation Model Technologies and Applications: The DEM Users Manual, American Society for Photogrammetry and Remote Sensing, 2001.

Moreno Baños, I., , Ruiz Garcia, A., Marturià, Alavedra, J., Oller I Figueras, P., Pina Iglesias, J., Garcia Selles, C., Martinez 
I Figueras, P., and Talaya Lopez, J.: Snowpack depth modelling and water availability from LIDAR measurements in eastern Pyrenees, 2009.

Mott, R., Schirmer, M., Bavay, M., Grünewald, T., and Lehning, M.: Understanding snow-transport processes shaping the mountain snow-cover, The Cryosphere, 4, 545-559, doi:10.5194/tc-4-5452010, 2010.

Mott, R., Scipion, D., Schneebeli, M., Dawes, N., Berne, A., and Lehning, M.: Orographic effects on snow deposition patterns in mountainous terrain, J. Geophys. Res.-Atmos., 119, 1419-1439, doi:10.1002/2013jd019880, 2014.

Peck, E. L. and Brown, M. J.: An approach to the development of isohyetal maps for mountainous areas, J. Geophys. Res., 67, 681694, doi:10.1029/JZ067i002p00681, 1962.

Rasmussen, R., Dixon, M., Hage, F., Cole, J., Wade, C., Tuttle, L., McGettigan, S., Carty, T., Stevenson, L., Fellner, W., Knight, S., Karplus, E., and Rehak, N.: Weather support to deicing decision making (WSDDM): A winter weather nowcasting system, Bull. Am. Meteorol. Soc., 82, 579-595, 2001.

Rasmussen, R. M., Hallett, J., Purcell, R., Landolt, S. D., and Cole, J.: The Hotplate Precipitation Gauge, J. Atmos. Ocean. Technol., 28, 148-164, doi:10.1175/2010jtecha1375.1, 2011.

Robichaud, A. J. and Austin, G. L.: On the modelling of warm orographic rain by the seeder-feeder mechanism, Q. J. Roy. Meteor. Soc., 114, 967-988, doi:10.1002/qj.49711448207, 1988.

Roe, G. H.: Orographic precipitation, Annu. Rev. Earth Planet. Sci., 33, 645-671, 2005.

Roe, G. H. and Baker, M. B.: Microphysical and Geometrical Controls on the Pattern of Orographic Precipitation, J. Atmos. Sci., 63, 861-880, doi:10.1175/jas3619.1, 2006.

Rohrer, M., Braun, L., and Lang, H.: Long-Term Records of Snow Cover Water Equivalent in the Swiss Alps 1. Analysis, Nordic Hydrology, 25, 53-64, 1994.

Sandau, R.: Digital Airborne Camera. Introduction and Technology, Springer, Heidelberg, Germany, 2010.

Schirmer, M., Wirz, V., Clifton, A., and Lehning, M.: Persistence in intra-annual snow depth distribution: 1 Measurements and topographic control, Water Resour. Res., 47, W09516, doi:10.1029/2010wr009426, 2011.

Scipion, D. E., Mott, R., Lehning, M., Schneebeli, M., and Berne, A.: Seasonal small-scale spatial variability in alpine snowfall and snow accumulation, Water Resour. Res., 49, 1446-1457, doi:10.1002/wrcr.20135, 2013.
Sevruk, B.: Regional dependency of precipitation-altitude relationship in the Swiss Alps, Clim. Change, 36, 355-369, 1997.

Shook, K. and Gray, D. M.: Small-scale spatial structure of shallow snowcovers, Hydrol. Proc., 10, 1283-1292, 1996.

Spreen, W.: A determination of the effect of topography upon precipitation, Transactions, American Geophysical Union, 28, 285 290, doi:10.1029/TR028i002p00285, 1947.

Trujillo, E., Ramirez, J. A., and Elder, K. J.: Topographic, meteorologic, and canopy controls on the scaling characteristics of the spatial distribution of snow depth fields, Water Resour. Res., 43, 1-17, doi:10.1029/2006WR005317, 2007.

Trujillo, E., Ramirez, J. A., and Elder, K. J.: Scaling properties and spatial organization of snow depth fields in subalpine forest and alpine tundra, Hydrol. Proc., 23, 1575-1590, doi:10.1002/Hyp.7270, 2009.

Turcan, J.: Snow storage distribution in mountain watersheds, Proceedings of the Moscow Snow and Ice-Symposium - Neige et Glaces, Moscow, Russia, August 1971, IAHS-AISH Publ, 104, 335-340, 1975.

Wastl, C. and Zängl, G.: Analysis of mountain-valley precipitation differences in the Alps, Meteorologische Zeitschrift, 17, 311321, doi:10.1127/0941-2948/2008/0291, 2008.

Watson, F. G. R., Anderson, T. N., Newman, W. B., Alexander, S. E., and Garrott, R. A.: Optimal sampling schemes for estimating mean snow water equivalents in stratified heterogeneous landscapes, J. Hydrol., 328, 432-452, doi:10.1016/j.jhydrol.2005.12.032, 2006.

Yang, D. Q., Goodison, B. E., Metcalfe, J. R., Golubev, V. S., Bates, R., Pangburn, T., and Hanson, C. L.: Accuracy of NWS 8 standard nonrecording precipitation gauge: Results and application of WMO intercomparison, J. Atmos. Ocean. Technol., 15, 5468, 1998.

Zängl, G.: The temperature dependence of small-scale orographic precipitation enhancement, Q. J. Roy. Meteor. Soc., 134, 11671181, doi:10.1002/qj.267, 2008.

Zängl, G., Aulehner, D., Wastl, C., and Pfeiffer, A.: Small-scale precipitation variability in the Alps: Climatology in comparison with semi-idealized numerical simulations, Q. J. Roy. Meteor. Soc., 134, 1865-1880, doi:10.1002/qj.311, 2008. 